\title{
ESTIMATIVA DO CONTEÚDO DE DNA DE DIFERENTES ACESSOS DE BANANEIRA: RELAÇÕES ENTRE NÍVEL DE PLOIDIA E GRUPOS GENÔMICOS ${ }^{1}$
}

\author{
RAFAEL HANSEN MADAIL ${ }^{2}$, LEILA APARECIDA SALES PIO, \\ SEBASTIÃO DE OLIVEIRA E SILVA ${ }^{5}$, MOACIR PASQUAL ${ }^{4}$
}

RESUMO - A determinação do nível de ploidia é muito importante, principalmente em programas de melhoramento genético que envolvem poliploides, a fim de possibilitar a escolha adequada dos materiais vegetais com os quais se deseja trabalhar. A relação entre o conteúdo de DNA de acessos de bananeira e sua ploidia ainda permanece controversa na literatura; assim, o presente trabalho teve como objetivo avaliar o conteúdo de DNA de acessos de bananeira com diferentes níveis de ploidia. Foram avaliados sete acessos tetraploides, quatro triploides e quatro diploides. A determinação do conteúdo foi realizada pela técnica de citometria de fluxo. Foram trituradas entre 50-60 mg de folhas frescas, juntamente com o padrão interno (Pisum sativum) no tampão LB01, e, posteriormente, as amostras foram filtradas em gaze e filtro de $50 \mu \mathrm{m}$. Adicionaram-se $5 \mu \mathrm{L}$ de RNase e $25 \mu \mathrm{L}$ de iodeto de propídeo. Para cada amostra, foram analisados 10 mil núcleos, com três repetições. Os resultados obtidos para o conteúdo de DNA permitiram estimar o tamanho dos genomas A e B, sendo o primeiro cerca de 14\% maior que o segundo. Os resultados apresentaram clara relação entre o conteúdo de DNA e o nível de ploidia dos materiais. O contéudo de DNA apresentou aumento médio de $30 \%$ nas cultivares diploides em relação às cultivares triploides avaliadas e de $25 \%$ nas cultivares triploides em relação às cultivares tetraploides. Apesar da diferença nos tamanhos dos genomas A e B, contribuições distintas desses dois genomas não foram diretamente relacionadas com alterações no conteúdo do DNA de cultivares tetraploides.

Termos para indexção: Musa sp. Conteúdo de DNA. Ploidia. Citometria de fluxo.

\section{ESTIMATE OF DNA CONTENT OF DIFFERENT ACCESS OF BANANA: RELATIONS BETWEEN PLOID LEVEL AND GENOME GROUPS}

\begin{abstract}
Ploidy determination is very important, especially in breeding programs, to allow the correct choice of plant material to work. The relation between DNA content and ploidy level still has some controversies in literature, so the present study had the aim of evaluate DNA content in banana accesses with different ploidy levels. Data were evaluated from six tetraploid, four triploids and four diploids accesses. 50-60 mg of leave material were crushed with material from internal standard (Pisum sativum) in LB01 buffer and then filtered through gauze and $50 \mu \mathrm{m}$ filter. It was added $5 \mu \mathrm{L}$ of RNase and $25 \mu \mathrm{L}$ of propide iodate. For each sample 10 thousand nuclei were analyzed with three repetitions. The DNA content results allowed separating genome A and B. Genome A appeared to be 14\% major than genome B. Results showed a clear relationship between DNA content and ploidy level. DNA content increased 30\% on average from diploid to triploid cultivars and $25 \%$ from triploid cultivars to tetraploid cultivars. Despite the size difference between genome A and B it could not be found a direct relationship between the contribution of these two genomes and the size of DNA content in tetraploid cultivars.
\end{abstract}

Index terms: Musa sp. DNA content. Ploidy. Flow cytometry.

${ }^{1}$ (Trabalho 195-14). Recebido em: 17-07-2014. Aceito para publicação em: 26-05-2015.

${ }^{2}$ Biólogo, D.Sc., Professor no Instituto Federal de Educação, Ciência e Tecnologia do Sul de Minas - IFSULDEMINAS, Câmpus Poços de Caldas. E-mail: rafael.madail@ifsuldeminas.edu.br

${ }^{3}$ Eng. Agrônoma, D.Sc., Professora no Departamento de Agricultura, Universidade Federal de Lavras - UFLA. E-mail: leilapio.ufla@ gmail.com

${ }^{4}$ Eng. Agrônomo, D.Sc., Professor no Departamento de Agricultura, Universidade Federal de Lavras - UFLA. E-mail: mpasqual@ dag.ufla.br

${ }^{5}$ Eng. Agrônomo, D.Sc., Pesquisador na EMBRAPA Mandioca e Fruticultura Tropical. E-mail: sebastiao.silva@colaborador.embrapa.br 


\section{INTRODUÇ̃̃O}

As bananeiras e os plátanos pertencem ao gênero Musa L. Acredita-se que a maioria das cultivares de bananeiras produzidas nos dias atuais apresente origem a partir de duas espécies diploides deste gênero: Musa acuminata e Musa balbisiana. Entretanto, as relações evolutivas entre essas espécies ao longo do processo de domesticação das bananeiras ainda são de difícil compreensão pela falta de informação disponível e limitação de técnicas e amostragem (LI et al., 2010). A ocorrência natural de híbridos interespecíficos, bem como a ampla utilização da propagação vegetativa, dificulta o esclarecimento da taxonomia do gênero Musa (HESLOP-HARRISON; SCHWARZACHER, 2007). As cultivares podem ser diploides, triploides ou tetraploides, sendo a maioria uma combinação de diferentes proporções dos genomas de $M$. acuminata -constituída pelo genoma A - e de M. balbisiana - constituída pelo genoma B (VALDEZ-OJEDA et al., 2014). Estas complexas relações genéticas dos materiais de bananeira podem, muitas vezes, dificultar os estudos de programas de melhoramento genético, bem como o desenvolvimento de novas cultivares pelo desconhecimento das características genômicas dos materiais a serem utilizados nos cruzamentos.

A informação gerada pela determinação do conteúdo de DNA, bem como do nível de ploidia, tem sido aplicada em variadas áreas da ciência (PELLICER; LEITCH, 2014), podendo ser de grande utilidade para programas de melhoramento, especialmente no caso da cultura da bananeira, possibilitando maior compreensão das relações entre as cultivares e contribuição dos diferentes genomas em sua formação, o que permitiria maior precisão na escolha dos materiais a fim de serem utilizados nos planos de trabalho.

A citometria de fluxo tem sido amplamente utilizada com o propósito de compreender a variação de conteúdo de DNA intraespecífico. A relação do conteúdo de DNA e a seleção por determinadas cultivares dentro de uma espécie são discutidas por Greilhuber (2005). De acordo com esse autor, o tamanho do genoma interfere no volume celular e na duração do ciclo celular. Assim, plantas com genoma menor apresentariam desenvolvimento mais rápido e, por conseguinte, estariam sendo selecionadas ao longo da evolução da agricultura.

Considerando a diversidade genômica e de níveis de ploidia do complexo Musa, o presente trabalho teve como objetivo avaliar o conteúdo de DNA de genótipos e cultivares de bananeira, relacionando-os com o nível de ploidia já conhecido para esses materiais a fim de se realizar inferências sobre a contribuição dos diferentes genomas no conteúdo de DNA.

\section{MATERIAL E MÉTODOS}

Foram utilizados sete acessos tetraploides, quatro triploides e quatro acessos diploides, com diferentes níveis de ploidia e combinações dos genomas A e B provenientes do Banco de Germoplasma da Embrapa Mandioca e Fruticultura. O material vegetal foi cultivado in vitro e posteriormente aclimatizado em casa de vegetação por 90 dias. Após este período, foram coletadas as amostras para a realização das análises de citometria de fluxo.

Foram utilizados aproximadamente 50-60 $\mathrm{mg}$ de folhas jovens de cada planta analisada. A ervilha (Pisum sativum L. $-9,09$ pg de DNA) foi utilizada como padrão interno. Este material foi triturado com auxílio de um bisturi, em placa de Petri, contendo $1 \mathrm{~mL}$ de tampão LB01 gelado para a liberação de núcleos. A suspensão de núcleos foi aspirada através de duas camadas de gaze com o auxílio de pipeta plástica e então filtrada em filtros de malha de $50 \mu \mathrm{m}$. Esta suspensão foi mantida em um recipiente com gelo para que não houvesse deterioração dos núcleos. Em seguida, foram adicionados à suspensão $25 \mu \mathrm{L}$ do fluorocromo iodeto de propídeo e $5 \mu \mathrm{L}$ de RNase. Foram analisados 10 mil núcleos para cada amostra, com três repetições. A análise foi realizada no citômetro FACSCalibur quatro cores (Becton Dickinson), e os histogramas foram obtidos com o software Cell Quest e analisados estatisticamente no software WinMDI 2.8 (TROTTER, 1998). O conteúdo de DNA nuclear (pg) das plantas foi estimado por comparação com a posição em relação ao pico G1 do padrão interno de referência (Pisum sativum). Os resultados foram submetidos à análise de variância; $\mathrm{e}$ as médias, agrupadas pelo teste de Scot-Knott, a 5\% de significância, no programa Sisvar (FERREIRA, 2010);

\section{RESULTADOS E DISCUSSÃO}

O conteúdo de DNA de 15 acessos de bananeira do banco de germoplasma da Embrapa Mandioca e Fruticultura está apresentado na Tabela 1.

Os coeficientes de variação encontrados para os picos G1 variaram de 0,45 a 2,06\%, caracterizando resultado bastante adequado, inferior ao encontrado em trabalhos muito citados com bananeira, como o de Dolezel et al. (1994), cujos coeficientes ficaram 
entre 2,5 e 4,5\%. Segundo Galbraith et al. (2002), coeficientes de variação de até $5 \%$ são aceitáveis.

A Figura 1 representa histogramas de acessos diploide (A), triploide (B) e tetraploide (C).

A análise de variância mostrou diferenças significativas entre os acessos avaliados $(\mathrm{P}<0,001)$. $\mathrm{O}$ conteúdo 2C de DNA nuclear dos genótipos diploides variou de 1,03 a 1,23 pg. Nos acessos triploides a variação ficou entre 1,40 e 1,54 pg e nos tetraploides entre 1,66 e 2,00 pg. (Tabela 1).

Menor conteúdo de DNA foi encontrado no diploide de M. balbisiana, Butuhan, com 1,03 pg. Trabalhos realizados por Jesus (2010), nos quais foram analisados 284 acessos de bananeira demonstraram valores um pouco maiores para os diploides BB, com média de 1,25 pg. No entanto, assim como no presente estudo, o genótipo Butuhan foi o que apresentou o menor conteúdo de DNA entre todos os diploides. O resultado de quantidade de DNA encontrado neste trabalho para M. balbisiana corrobora o estudo de Jenny et al. (1997), que estabelece o valor 2C de 1,03 pg como sendo característico para o genoma B (D'HONT et al., 2000).

Para os acessos diploides de $M$. acuminata, os valores foram significativamente maiores que os relatados na literatura, ficando entre 1,11 e 1,23 pg. Jesus (2010) encontrou valores próximos, com média de $1,25 \mathrm{pg}$. O valor encontrado para o conteúdo de DNA do genótipo 118 diferiu estatisticamente dos demais genótipos AA: Malbut e NBA. Estes valores encontrados, em geral para o material diploide, concordam com os observados em vários outros estudos prévios como os de Dolezel et al. (1994), Kamaté et al. (1999), Lysák et al. (1999) e Asif et al. (2001). Outros autores, estabelecem como 1,11 o valor 2C característico para o genoma A (JENNY et al., 1997).

É importante salientar que Jesus (2010) classificou o genótipo Malbut como sendo um mixoploide, enquanto o presente estudo o coloca claramente como um diploide (Figura 2).

Como era esperado, a estimativa do conteúdo de DNA nuclear pela técnica de citometria de fluxo foi capaz de diferenciar o tamanho dos genomas A e B. Em média, o genoma A apresentou-se 14\% maior que o genoma B. Esse valor mostrou-se próximo aos valores encontrados em outros estudos, como o de Dolezel et al. (1994), que foi de 10\%; o trabalho de Lysák et al. (1999), que encontrou diferença de $12 \%$, e o estudo de Kamaté et al. (2001), no qual o genoma A se mostrou $15 \%$ maior que o genoma B. Também Asif et al. (2001) encontraram valores superiores aos $10 \%$ na diferença entre os genomas
A e B. Jesus (2010), entretanto, não diagnosticou diferenças significativas entre os conteúdos de DNA nuclear para os genomas A e B.

Diferenças na quantidade de DNA também têm sido observadas dentro de M. acuminata. Assim como Lysák et al. (1999), o presente trabalho encontrou variação significativa entre alguns dos acessos diploides AA. Esta variação, no entanto, mostrou-se abaixo do esperado, uma vez que a literatura descreve grandes variações intraespecíficas em espécies cultivadas (GREILHUBER, 2005). Conteúdos diferentes de DNA nos acessos AA podem ser resultantes do isolamento geográfico criado entre muitas das cultivares de bananeira utilizadas nos trabalhos de quantificação de conteúdo de DNA. Não se sabe até que ponto tais variações relatadas na literatura seriam artefatos criados pela técnica ou seriam realmente questões de plasticidade genômica. Desse modo, essas questões ainda merecem maior atenção por parte dos especialistas.

Os acessos triploides apresentaram valores entre 1,40 pg (Prata-Anã) e 1,54 pg (Caipira). O acesso Caipira, que possui somente genoma $\mathrm{A}$ em sua constituição, apresentou o maior valor absoluto de conteúdo de DNA; entretanto, esse não diferiu estatisticamente dos acessos AAB Maçã e Thap Maeo. Assim, a relação entre os grupos genômicos e o conteúdo de DNA não pode ser considerada nos acessos triploides.

Os valores encontrados para as cultivares triploides diferem daqueles observados por Kamaté et al. (2001), Lysák et al. (1999) e Jesus (2010). Os primeiros autores encontraram conteúdos variando entre 1,64 e 2,23 pg, sendo este último valor bastante discrepante dos demais, enquanto os valores encontrados por Lysák et al. (1999) ficaram entre 1,73 e 1,90 pg. Jesus (2010) encontrou valores de 1,86 até $1,99 \mathrm{pg}$.

Considerando acessos triploides com diferentes constituições genômicas, Lysák et al. (1999) relatam que o valor esperado para os diferentes grupos é de 1,66 a 1,68 pg para acessos $\mathrm{BBB}$, de 1,72 a 1,76 pg para acessos $\mathrm{ABB}$, de 1,78 a 1,84 para acessos $\mathrm{AAB}$ e de 1,84 a 1,91 pg para acessos AAA.

As cultivares triploides apresentaram menor diferença no conteúdo genômico do que os acessos diploides, sendo que a diferença entre o maior e o menor conteúdo medidos foi de $10 \%$. Esse valor foi o mesmo encontrado para o material triploide no estudo realizado por Lysák et al. (1999), no qual a diferença entre os diploides e triploides foi a mesma (10\%). Kamaté et al. (2001), entretanto, encontraram diferença de cerca de $39 \%$ entre o maior e o menor 
conteúdo de DNA nas cultivares triploides.

As cultivares tetraploides apresentaram variação maior no conteúdo de DNA, sendo que a diferença entre o maior e o menor valor foi de $20 \%$. Jesus (2010) cita que maior variação encontrada no conteúdo de DNA entre os acessos tetraploides do que entre os triploides $(0,13$ e $0,28 \mathrm{pg}$, respectivamente) se deve, provavelmente, por este germoplasma resultar de diferentes cruzamentos. De acordo com esse autor, tal diferença é esperada pelo fato de haver maior possibilidade de combinações entre os genomas em acessos tetraploides.

Os valores encontrados para o conteúdo de DNA dos acessos tetraploides por Jesus (2010) variaram de 2,28 a 2,56 pg. Kamaté et al. (2001) avaliaram apenas dois acessos AAAA e encontraram valores um pouco menores, de 2,37 e 1,94 pg, mais próximos aos encontrados neste estudo.

Como observado por Lysák et al. (1999), o conteúdo de DNA para os acessos tetraploides nesse estudo encontram-se na faixa próxima ao esperado para acessos triploides AAA. Da mesma forma, os resultados encontrados por Jesus (2010) para os acessos triploides foram superiores aos valores propostos por aqueles autores. Diferenças dessa natureza têm sido comumente encontradas na literatura e acredita-se que possam ser resultantes de questões técnicas, como preparação das amostras, uso de diferentes citômetros de fluxo ou do padrão interno considerado.
No presente estudo, assim como no de Jesus (2010), foi utilizado como padrão interno o DNA da ervilha (Pisum sativum), que possui um conteúdo $2 \mathrm{C}$ de 9,09 pg. Alguns autores consideram Pisum sativum como uma excelente alternativa de padrão interno por possuir um conteúdo de DNA que se situa + no meio do valor médio para a maioria dos conteúdos de DNA vegetal, podendo, desta forma, ser utilizada para avaliar tanto plantas com um pequeno genoma quanto plantas com um genoma grande (DOLEZEL; BARTOS, 2005). Além disso, o genoma nuclear dessa espécie é estável, e o preparo de suspensões de núcleos a partir de suas folhas não libera compostos que interferem na coloração pelo iodeto de propídeo.

Como relatado na literatura, os limites de valores para o conteúdo de DNA de Musa com diferentes ploidias encontram-se muitas vezes sobrepostos e, comumente, uma cultivar apresenta um conteúdo diferente do esperado pela sua ploidia e combinação genômica. Lysák et al. (1999) especulam que o principal motivo pelo qual isto acontece é o fato de que estes diferentes materiais passam pelo processo de isolamento geográfico e pela propagação vegetativa, que são fatores extremamente relevantes para promoverem alterações no tamanho do genoma da planta. Segundo Çelikler e Bilaloglu (2001), variações como estas no conteúdo de DNA podem ser decorrentes de baixa replicação da heterocromatina, decréscimo na quantidade de sequências altamente repetidas e mutações ou adaptações em relação a fatores ambientais. Desta forma, plantas que exibem a mesma origem, a mesma ploidia e a mesma razão entre a contribuição do genoma A e B podem apresentar conteúdos de DNA bastante distintos. 

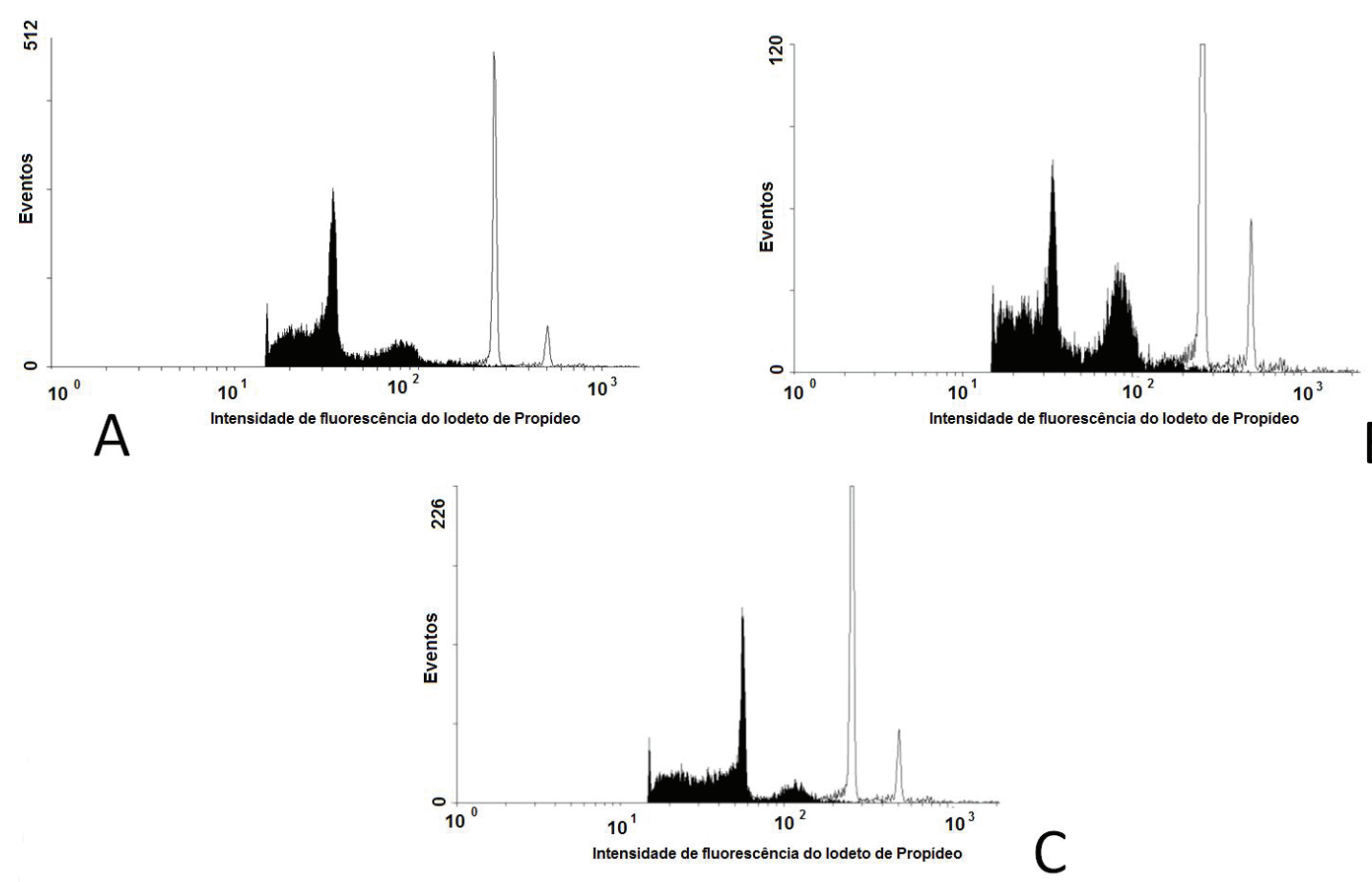

FIGURA 1- Histogramas representando acessos diploide (A), triploide (B) e tetraploide (C) de genótipos de bananeira (em preto) e o padrão de referência (Pisum sativum) em branco.

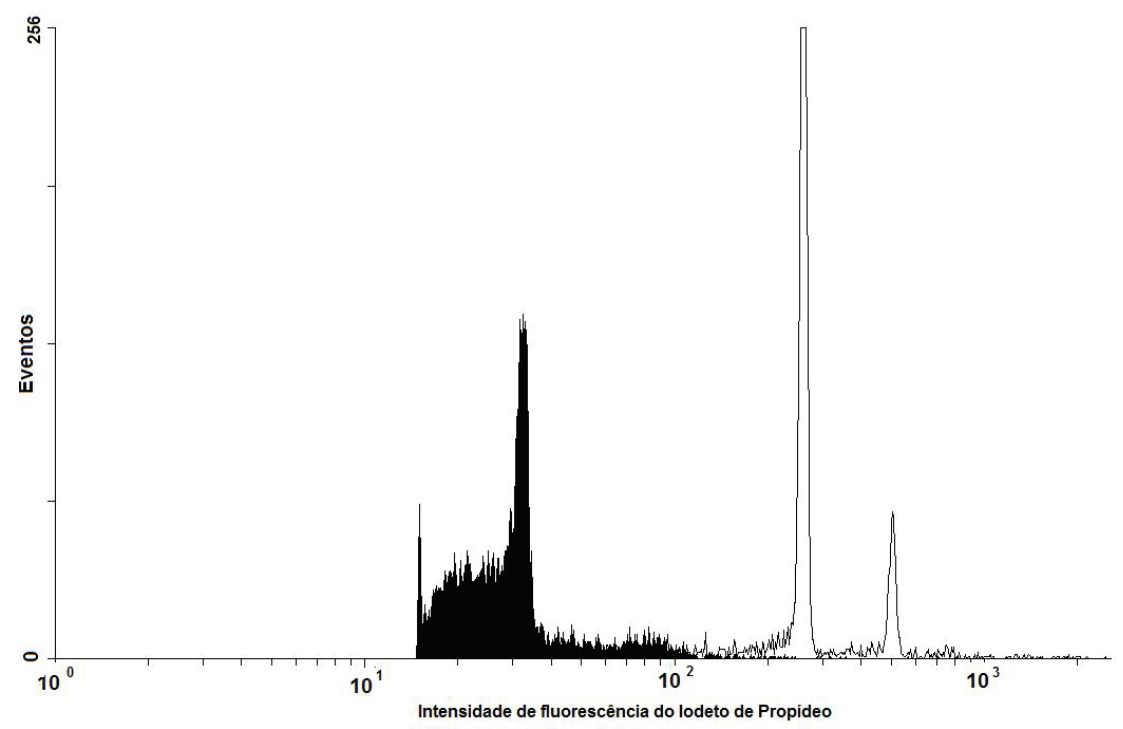

FIGURA 2- Histograma representando o acesso diploide AA Malbut. 
TABELA 1 -Conteúdo de DNA estimado por citometria de fluxo para acessos de bananeira com diferente níveis de ploidia.

\begin{tabular}{ccc}
\hline Acessos & Grupo Genômico & $\begin{array}{c}\text { Conteúdo de DNA } \\
\text { (pg) }\end{array}$ \\
\hline Bucanero & AAAA & $2,00 \mathrm{~A}$ \\
Tropical & AAAB & $1,99 \mathrm{~A}$ \\
102 & AAAA & $1,95 \mathrm{~A}$ \\
PA42-44 & AABB & $1,86 \mathrm{~B}$ \\
Princesa & AAAB & $1,86 \mathrm{~B}$ \\
FHIA 02 & AAAA & $1,82 \mathrm{~B}$ \\
Garantida & AAAB & $1,66 \mathrm{C}$ \\
Caipira & AAA & $1,54 \mathrm{D}$ \\
Maçã & AAB & $1,53 \mathrm{D}$ \\
Thap Maeo & AAB & $1,51 \mathrm{D}$ \\
Prata-Anã & AAB & $1,40 \mathrm{E}$ \\
Malbut & AA & $1,23 \mathrm{~F}$ \\
NBA & AA & $1,22 \mathrm{~F}$ \\
118 & AA & $1,11 \mathrm{G}$ \\
Butuhan & BB & $1,03 \mathrm{H}$ \\
\hline
\end{tabular}

Médias seguidas pela mesma letra dentro da coluna pertencem ao mesmo grupo, segundo o teste de Scott-Knott, a 5\% de probabilidade.

\section{CONCLUSÃO}

Os valores encontrados para a estimativa do conteúdo de DNA em bananeira permitiram a separação dos diferentes acessos de acordo com seu nível de ploidia. Não foi observada clara relação entre a contribuição dos genomas A e B e o conteúdo de DNA.

\section{REFERÊNCIAS}

ASIF, M.; MAK, C.; OTHMAN, Y. Characterization of indigenous Musa species based on flow cytometric analysis of ploidy and nuclear DNA content. Caryologia, Firenze, v. 54, n. 2, p. 161-168, 2001. 91.

ÇELIKLER, S.; BILALOGLU, R. Nucleotipic effects in different genotypes of Vicia faba L. Turkish Journal of Biology, Ankara, v. 25, n. 4, p. 205-219, 2001.

D'HONT, A. The interspecific genome structure of cultivated banana, Musa spp. revealed by genomic DNA in situ hybridization. Theoretical and Applied Genetics, Berlin, v. 100, n. 2, p. 177-183, 2000.
DOLEZEL, J.; BARTOS, J. Plant DNA flow cytometry and estimation of nuclear genome size. Annals of Botany, London, v. 95, n. 3, p. 99-110, 2005.

DOLEZEL, J.; DOLEZELOVA, M.; NOVÁK, F. Flow cytometric estimation of nuclear DNA amount in diploid bananas (Musa acuminata and Musa balbisiana). Biologia Plantarum, Copenhagen, v. 36, n. 3, p. 351-357, 1994.

FERREIRA, D. Programa computacional Sisvar. versão 5.3. Lavras: UFLA, 2010.

GALBRAITH, D.; LAMBERT, G.; MACAS, J.; DOLEZEL, J. Analysis of nuclear DNA content and ploidy in higher plants. In: ROBINSON, J.; AZMI, A.; TUTOIS, S. (Ed.). Current protocols in cytometry. New York: J.Wiley, 2002. p. 7.6.17.6.22.

GREILHUBER, J. Intraespecific variation in genome size in Angiosperms: identifying its existence. Annals of Botany, London, v. 95, n. 1, p. 91-98, 2005. 
HESLOP-HARRISON, J.; SWARZACHER, T. Domestication, genomics and the future of banana. Annals of Botany, London, v. 100, p. 1073-1084, 2007.

JENNY, C.; CARREEL, F.; BAKRY, F. Revision on banana taxonomy. 'Klue Tiparot' (Musa sp.) reclassified as a triploid. Fruits, Paris v. 52, n.2, p.83-91, 1997.

JESUS, O. de. Caracterização molecular de acessos de bananeira do banco de germoplasma da Embrapa. 2010. 138 f. Tese (Doutorado em Genética e Melhoramento de Plantas) - Escola Superior de Agricultura “Luiz de Queiroz", Universidade de São Paulo, Piracicaba, 2010.

KAMATÉ, K.; BROWN, S.; DURAND, P.; BUREAU, J.; DE NAY, D.; TRINH, T. Nuclear DNA content and base composition in 28 taxa of Musa. Genome, Ottawa, v. 44, n. 4, p. 622-627, 2001.

LI, L.; HÄNNIKEN, M.; YUAN, Y.; HAO, G.; GE, $\mathrm{X}$. Molecular phylogeny and systematics of the banana family (Musaceae) inferred from multiple nuclear and chloroplast DNA fragments, with special reference to the genus Musa. Molecular Phylogenetics and Evolution, Amsterdam, v.57, n.1, p.1-10, 2010.
LYSÁK, M.; DOLEZELOVA, M.; HORRY, J.; SWENNEN, R.; DOLEZEL, J. Flow cytometry analysis of nuclear DNA content in Musa. Theoretical and Applied Genetic, Berlin, v. 98, n. 8, p. 13441350, 1999.

PELLICER, J.; LEITCH, I. The application of flow cytometry for estimating genome size and ploidy level in plants. Methods in Molecular Biology, Clifton, v. 1115, p. 279-307, 2014.

TROTTER, J. WinMDI: Windows multiple document interface for flow cytometry. Versão 2.8. La Jolla: Scripps Research Institute, 1998.

VALDEZ-OJEDA, R.; JAMES-KAY, A.; KUCAUICH, J.; ESCOBEDO-GRACIAMEDRANO, R. Genetic relationships among a collection of Musa germplasm by fluorescent-labeled SRAP. Tree Genetics and Genome, Berlin, v. 10, p. 465-476, 2014. 